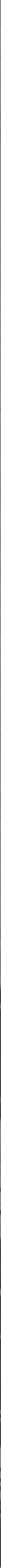




\title{
Availability of Ground Water at the Border Stations at Laurier and Ferry, Washington
}

\author{
By K. L. Walters
}

Prepared in cooperation with the General Services Administration

$$
\lambda
$$

Geological Survey Circular 422 
United States Department of the Interior FRED A. SEATON, SECRETARY

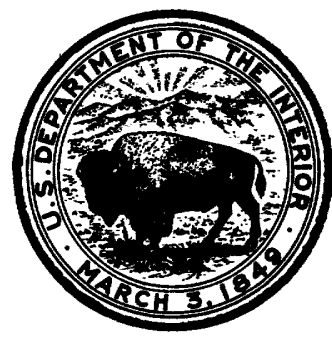

Geological Survey

THOMAS B. NOLAN, DiRECTOR

x

Free on epplicotion to the U.S. Geological Survey, Washington 25, D. C. 


\section{CONTENTS}

$\begin{array}{llll} & & \\ \text { Abstract } & & \\ \text { Introduction. } & \text { Gage } \\ \text { Well-numbering system } & \text { Laurier } \\ \text { Geologic setting at Laurier } & \text { Geologic setting at Ferry } & \end{array}$

\section{ILLUSTRATIONS}

Figure 1. Map of the State of Washington showing area covered by this investigation

2. Sketch showing well -numbering system

3. Geological features and location of selected wells in the Kettle River

4. Geological features and location of selected wells in the Kettle River valley at Ferry, Wash 


\title{
Availability of Ground Water at the Border Stations at Laurier and Ferry, Washington
}

\author{
By K. L. Walters
}

\begin{abstract}
ARSTRACT
In the Laurier area, Washington, the Kettle River has cut into crystalline rocks in the deepest part of the valley. Sand and gravel fill were deposited in the valley during Pleistocene time by melt water from glaciers, and subsequent erosion and alluviation formed three terrace levels. The highest level, on which Laurier Border Station is situated is about 200 feet above present river level. The intermediate terrace is 150 to 180 feet above river level. Wells on the intermediate terrace yield about $4 \mathrm{gpm}$ (gallons per minute) per foot of drawdown. Larger yields probably could be obtained from wells on the lowest terrace (flood plain).

In the Ferry area the valley fill of the Kettle River valley is as much as 150 feet thick and contains boulders that are as much as 18 inches in diameter. Small to moderate quantities of water probably would be available from wells on the high-terrace level. Large quantities of water are obtained from irrigation wells on the low terrace.
\end{abstract}

The bedrock at both sites is relatively impermeable and probably would yield very meager supplies of water.

\section{INTRODUCTION}

This report outlines the general groundwater conditions in the valley of the Kettle River near the international boundary in Ferry County, Wash., an area in which little is known regarding the occurrence and avail ability of ground water. The field work upon which this report is based was done in April 1959 at the request of the General Services Administration to determine the availability of ground-water supplies for the Customs and Immigration Stations at Laurier and at Ferry, Wash. Although only a brief reconnaissance of the area was made, this report has been prepared to make available the results of this study.

Many interesting geologic and hydrologic aspects of the area were observed, but a de tailed study of them was beyond the scope of this investigation. A detailed investigation of a much larger segment of the Kettle River valley would materially increase the knowledge of the geology and occurrence of ground water in the area.
The Kettle River occupies a broad glaciated valley which enters the United States from Canada at Ferry, re-enters Canada at Danville, and, just north of the international boundary, flows east for about 12 miles until it enters the United States again at Laurier. From Laurier the valley trends slightly east of south for about 25 miles, where it joins the valley of the Columbia River near Marcus, Wash. The Kettle River valley is incised into a complex system of igneous and metamorphic rocks and has a well-developed system of alluvial terraces.

Mining and lumbering are the principal industries of the upland areas bordering the Kettle River valley; diversified farming is practiced in suitable parts of the valley it self. In Canada, several irrigation wells have been drilled in the Kettle River valley, near Grand Forks, about 9 miles northwest of Laurier; and near Midway, which is about half a mile north of the international boundary at Ferry. The average annual precipitation at Laurier is about 18.5 inches. August is generally the driest month, and December the wettest. Temperatures range from $110^{\circ}$ to. $-30^{\circ} \mathrm{F}$. The location of the area is shown on figure 1 .

\section{WELL-NUMBERING SYSTEM}

Well numbers used by the Geological Survey in the State of Washington are based on and show the location of wells according to the rectangular system for subdivision of public land, indicating township, range, section, and 40-acre tract within the section. For example, in the well number 40/36-3B2, the part preceding the hyphen indicates successively the township and range (T. $40 \mathrm{~N}$., R. $36 \mathrm{E}$.$) north and east of the Willamette$ base line and meridian. (Because all townships in Washington are north of the Willamette base line the letter " $N$," indicating north, 


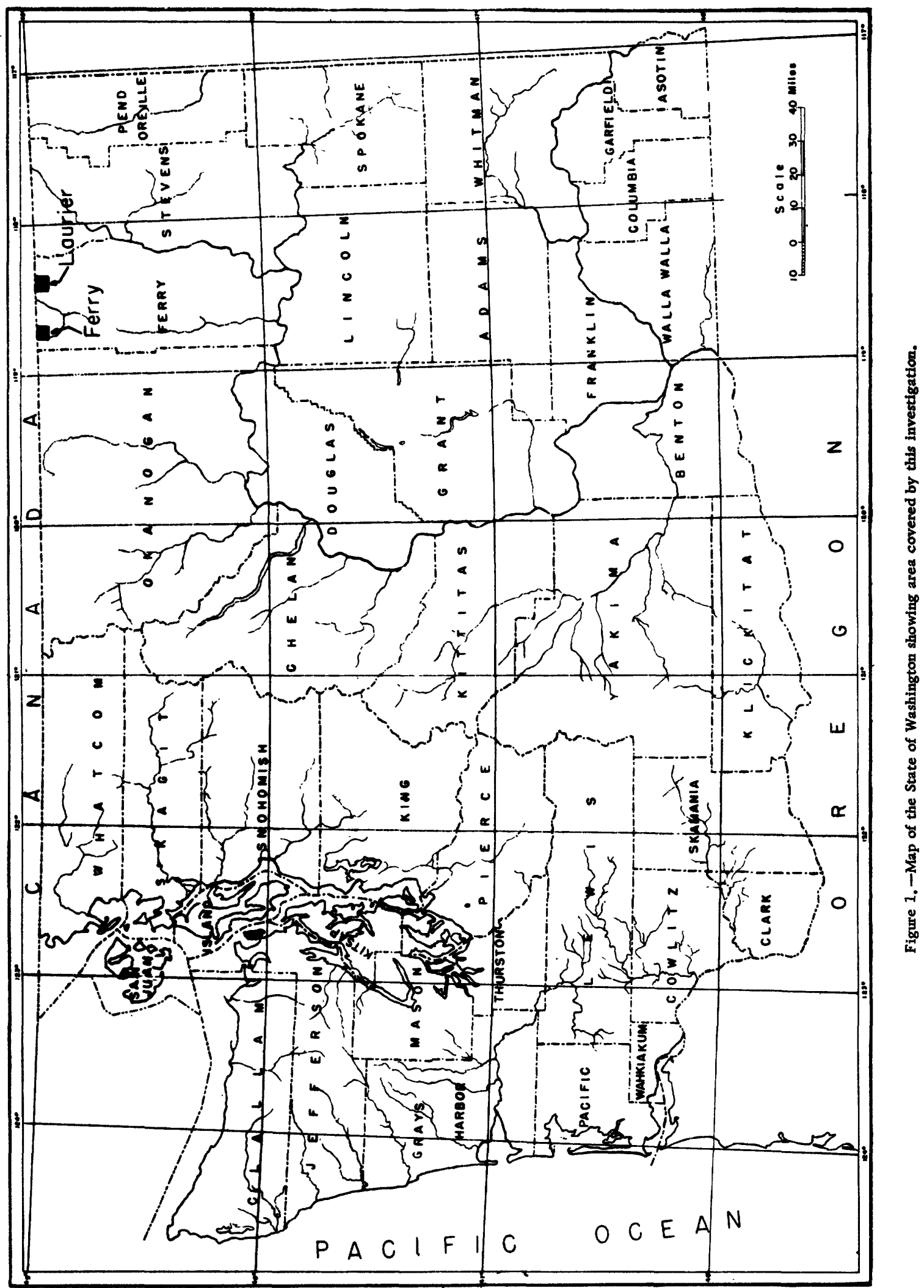


is omitted; and because most of the State is east of the Willamette meridian the letter " $E$ " is omitted for those ranges east of the Wil lamette meridian, but " $W$ " is included for those ranges west of the Willamette meridian.) The first number after the hyphen indicates the section (sec. 3), and the letter (B) gives the 40-acre subdivision of the section as shown in the diagram (fig. 2). The last

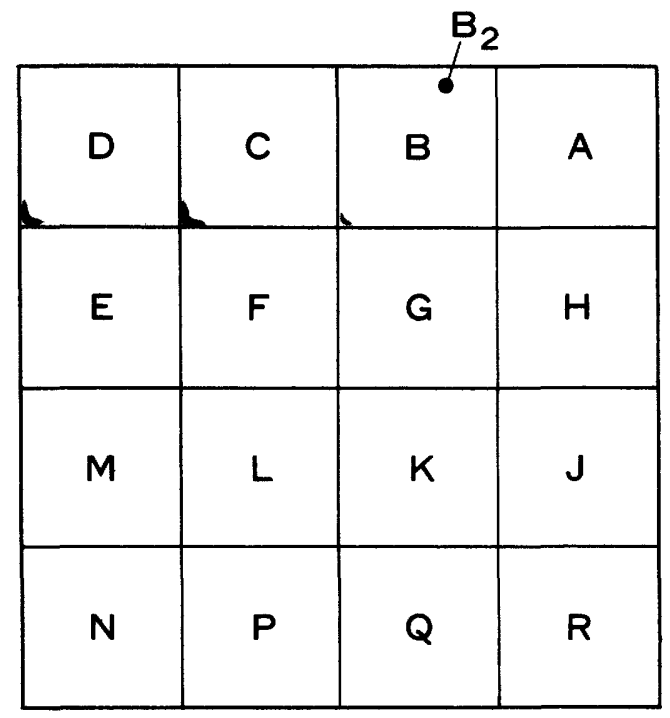

Sec. 3

Figure 2. -Sketch showing well-numbering system.

number (2) is the serial number of the well in that particular 40-acre tract. Thus, the first well recorded in the NW $\frac{1}{4} N E \frac{1}{4}$ sec. 3 , T. $40 \mathrm{~N}$., R. $36 \mathrm{E}$., would have the number $40 / 36-3 B 1$, and the second well would have the number $40 / 36-3 B 2$.

\section{GEOLOGIC SETTING AT LAURIER}

At Laurier, the deepest part of the valley of the Kettle River has cut into crystalline rocks having the appearance of gneissic diorite. The bedrock exposed in the higher hills bordering the valley was not examined and the nature of these rocks was not deter mined. The valley of the Kettle River, and also the valley occupied by Christina Lake, about 3 miles north, in Canada, were glacially formed or, at least, were modified by gla ciers to approximately their present form. The valleys subsequently were filled to a depth of about 200 feet above present river level with sand, gravel, and cobbles, as much as 6 inches in diameter, deposited in part by melt water of the receding glaciers. In the Laurier area, beds of very fine sand and varved clays, suggest lake-bed deposition.
These beds were observed about 30 to 50 feet above the river level.

The original partial filling of the valley was followed by alternate downcutting and alluviation, resulting in a complex system of terrace levels. In all, three separate terraces were observed; these are designated the high, intermediate, and low (flood-plain) terraces in figure 1 . The terrace on which the Laurier Border Station is situated is the highest terrace that was observed in the area. It exists only as relatively small remnants, except where it is protected from erosion by ridges or fingers of bedrock extending from the valley wall.

On the west side of the Kettle River, a flat surface extends from the international bound ary southward for nearly 2 miles. This surface, representing the intermediate terrace, is 20 to 50 feet lower than that on which the border station is located. Because the material underlying this surface appears to be identical to the material underlying the border station, at least where exposed in several places along the river bluff, the lower surface probably represents a terrace cut into the sediments forming the upper terrace. The lower surface is present also on the east side of Kettle River. The easterly extent of this terrace is not shown in figure 3.

A band of flood-plain and low-terrace deposits ranging in width from about 800 feet to more than half a mile borders the channel of the Kettle River. The thickness of these deposits was not determined, but locally as much as 20 feet of sand, gravel, and well rounded boulders are exposed. No differentiation is made in figure 3 between floodplain and low-terrace deposits.

\section{GROUND-WATER CONDITIONS AT LAURIER}

Data were obtained for five wells situated on the high terrace, on which the Laurier Border Station stands. Complete information was available, however, only for well 40/363B2, which supplies water for the United States Border Station. This well was drilled in 1939 to a reported depth of 203 feet, and is equipped with an 8 -inch steel casing. The yield of the well is about $15 \mathrm{gpm}$, a rate ade quate for domestic use and some sprinkling of lawns. The 3-horsepower jet pump with which the well is equipped does not, however, supply enough water for fire protection and 


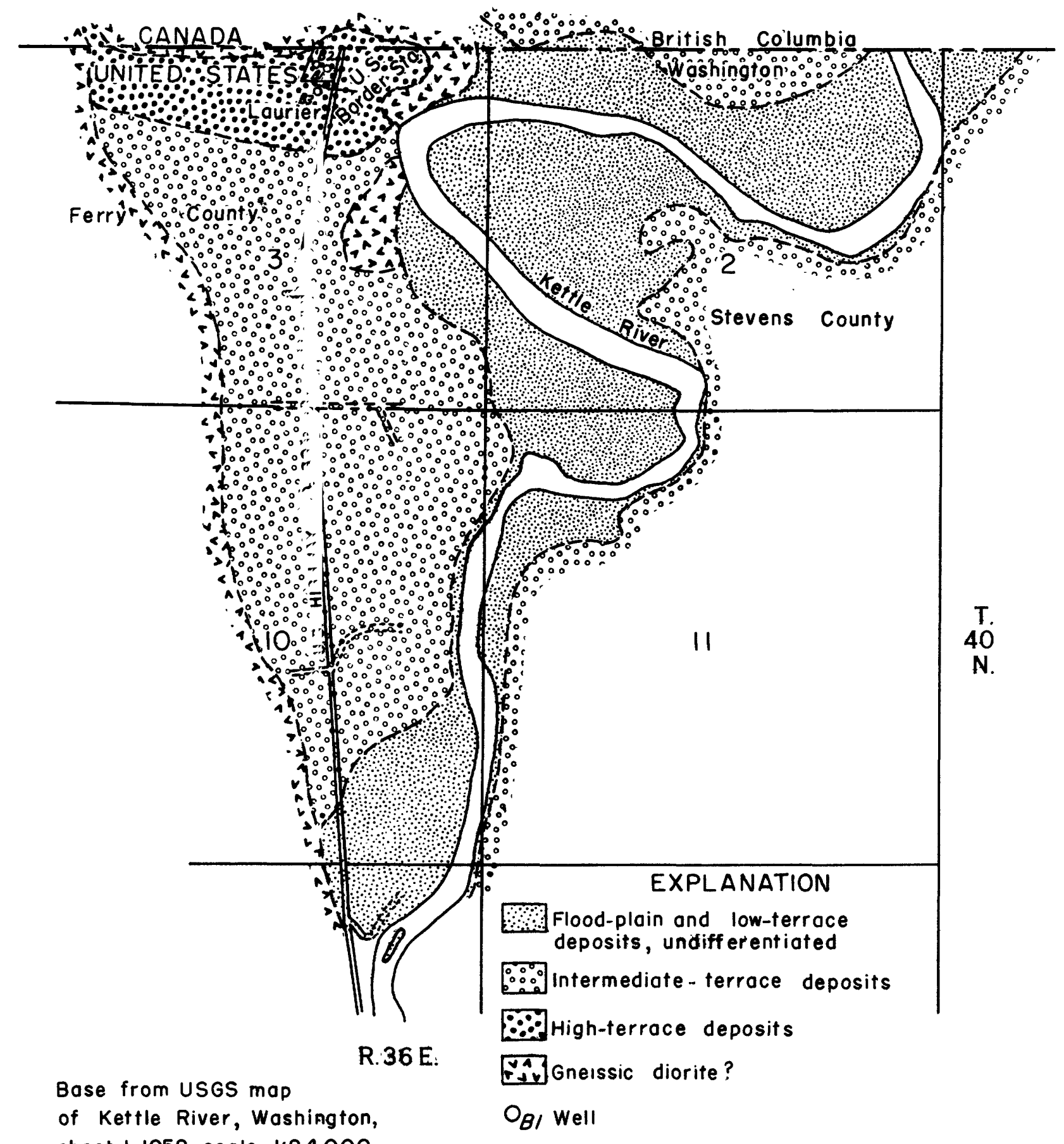

sheet 1,1952 , scale $1: 24,000$

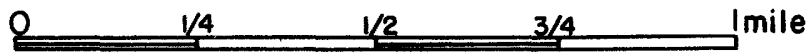


for sprinkling of additional lawn areas. The driller's log of the well is shown in the following table:

United States Border Station, Laurier, Wash. About 22 feet west of Customs Office

$$
\text { 40/36-3B2 }
$$

[Altitude, 1,647 feet. Drilled, 1939, by A. M. Edwards, Lexington, Oreg.]

\begin{tabular}{|c|c|c|}
\hline Materials & $\begin{array}{l}\text { Thick- } \\
\text { ness } \\
\text { (feet) }\end{array}$ & $\begin{array}{l}\text { Depth } \\
\text { (feet) }\end{array}$ \\
\hline Not reported. & 6 & 6 \\
\hline Sand and gravel & 14 & 20 \\
\hline Not reported. & 4 & 24 \\
\hline Gravel, coarse, loose........ & 16 & 40 \\
\hline Gravel, coarse, packed $\ldots . .$. & 6 & 46 \\
\hline Sand, fine & 41 & 87 \\
\hline $\begin{array}{l}\text { Sand, fine, silty; some brown } \\
\text { and yellow clay and } \\
\text { shale(?) }\end{array}$ & 49 & 136 \\
\hline Shale(?) & 2 & 138 \\
\hline Clay, blue & 18 & 156 \\
\hline Gravel & 6 & 162 \\
\hline Clay, yellow & 2 & 164 \\
\hline $\begin{array}{l}\text { "Quicksand" (water rose in } \\
\text { well } 15 \mathrm{ft} \text { ) }\end{array}$ & 12 & 176 \\
\hline Shale(?) & 2 & 178 \\
\hline Sand, coarse, and water..... & 10 & 188 \\
\hline Shale(?) and yellow clay ....- & 2 & 190 \\
\hline Not reported. & 4 & 194 \\
\hline Sand & 5 & 199 \\
\hline $\operatorname{Rock}(?)$ & 1 & 200 \\
\hline Clay, blue & 3 & 203 \\
\hline
\end{tabular}

Casing: 8-inch, set to bottom, screened 194$199 \mathrm{ft}$.

On April 21, 1959, measurements of water level were made on well 40/36-3B2 during both pumping and nonpumping conditions to determine the yield characteristics, as shown in the following table:
The water-level measurement of 126.20 feet, taken 1:30 p.m. on April 21, probably is representative of static or near-static conditions. The drawdown at 4:15 p.m., after 2 hours 41 minutes of pumping, was, therefore, 3.70 feet, giving a specific capacity of about $4 \mathrm{gpm}$ per foot of drawdown. These data indicated that the yield of this well could be in creased several fold without excessive drawdown. Although the driller's log does not show the presence of fine sand opposite the screened portion of the casing, some sand might be pumped during redevelopment if the pumping rate of the well were increased materially.

Well 40/36-3B1 is about 42 feet east of 40/36-3B2 (fig. 3), and is in the basement of the U.S. Customs Office. This well has been unused since completion of well 3B2 in 1939. It was reported that the well was abandoned because of sand entering. The present depth is 188.7 feet below the land surface; the original depth is not known. No information on the construction of this well is available except that it has an 8-inch steel casing. Measurements of the water level in well 40/36-3B1 that were made on April 21, 1959, are shown in the table on the following page.

The foregoing data show that during the pumping period of well 3B2, from 9:00 a.m. to 10:34 a.m. on April 21, the level in well 3B1 declined at least 0.12 foot. Within about $2 \frac{1}{2}$ hours after 3B2 was shut off, the level in 3B1 recovered 0.08 foot. Obviously, pumping the one well affects the water level in the other. The effect is slight, however. If it were known definitely how closely well 3B1 is hydraulically connected with the pumped well, it could be assumed that any new well could be located equally close, about 42 feet, to the pumped well without undue mutual interference. However, if well $3 \mathrm{~B} 1$ is partially, or nearly completely, sealed off from the

\begin{tabular}{|c|c|c|c|}
\hline Date & Time & $\begin{array}{c}\text { Depth to } \\
\text { water (feet } \\
\text { below land } \\
\text { surface) }\end{array}$ & Remarks \\
\hline Apri, 20, 1959 & 5:00 p.m... & $-n-n-n-n$ & Pump stopped. \\
\hline Apr. $21,1959 \ldots \ldots$ & 9:00 a.m..- & $-\ldots-n-n-m$ & Pump started; estimated rate, $15 \mathrm{gpm}$. \\
\hline Do & $10: 34$ a.m.-. & $-\cdots-n-n$ & Pump stopped. \\
\hline Do & $1: 30$ p.m.-- & 126.20 & \\
\hline Do & $1: 34 \frac{1}{2}$ p.m.- & $-\cdots--n-n$ & Pump started; estimated rate, $15 \mathrm{gpm}$. \\
\hline Do & $1: 41$ p.m...- & 129.40 & \\
\hline Do & $2: 34$ p.m.-- & 129.93 & \\
\hline Do & $4: 10$ p.m... & 129.90 & \\
\hline
\end{tabular}




\begin{tabular}{|c|c|c|}
\hline Time & $\begin{array}{c}\text { Depth to } \\
\text { water (feet } \\
\text { below land } \\
\text { surface) }\end{array}$ & Remarks \\
\hline $9: 45$ a.m & 124.36 & $\begin{array}{l}\text { Well } 40 / 36-3 \mathrm{~B} 2 \\
\text { had been pump- } \\
\text { ing since } 9: 00 \\
\text { a.m., April } 21 \text {, } \\
1959 \text {. }\end{array}$ \\
\hline 10:00 a.m. & 124.47 & \\
\hline 10:18 a.m. & 124.49 & \\
\hline $10: 34$ a. $\mathrm{m}_{-}$ & 124.48 & $\begin{array}{l}\text { Pumping of well } \\
40 / 36-3 \mathrm{~B} 2 \\
\text { stopped. }\end{array}$ \\
\hline $10: 36 \frac{1}{2}$ a.m & 124.48 & \\
\hline $10: 47$ a.m & 124.48 & \\
\hline $11: 50$ a.m. & 124.41 & \\
\hline 1:00 p.m & 124.40 & \\
\hline
\end{tabular}

water-yielding materials tapped by the pumped well, the pumping effect on other wells at a distance of 42 feet may be much greater than observed. For this reason, any new drilling site should be located not closer than about 100 feet from well 3B2, particularly inasmuch as both wells may be pumped simultaneously for extended periods of time. A privately owned, drilled well (40/36-3B3), about 450 feet south of $40 / 36-3 B 1$, supplies adequate domestic water for one house, a small store, and a house trailer. This well was reported to be about 145 feet deep. The Canadian Border Station, just north of the international boundary, has two drilled wells, the combined yield of which is reported to be adequate for domestic use and for lawn sprinkling. The location of the Canadian Border Station wells is not shown on figure 3.

There are no known wells on the intermediate terrace, which is traversed by U.S. Highway 395 for about 2 miles south of the international boundary. However, it would appear the yields from wells drilled in this area would be about the same as that of 40/36 -3B2. Comparatively large yields with relatively small drawdown could be expected from properly constructed wells drilled on the flood plain and low terrace along the Kettle River. No wells are known to tap the bedrock of the area, and it is unlikely that bedrock wells in this area would yield appreciable quantities of water.

\section{GEOLOGIC SETTING AT FERRY}

At Ferry the upland areas bordering the Kettle River valley are composed of intrusive igneous rocks. Here, as at Laurier, the valley was formed at least in part by glaciation and subsequently was filled to a depth of more than 150 feet with coarse sand, gravel, and well-rounded boulders as much as 18 inches in diameter, transported in part by melt waters of the receding glaciers. These deposits are preserved in a narrow band resting on the sides of the bedrock hills on both sides of the Kettle River almost continuously from the international boundary to more than a mile south. An unusually good exposure of these deposits is near the $\mathrm{N} \frac{1}{4}$ corner of sec. 10, T. 40 N., R. 32 E., where about 120 feet of sand and gravel is exposed above river level.

The United States Border Station at Ferry is situated on a terrace about 100 feet lower than the outwash terrace described above. Good exposures of the intermediate-terrace deposits were not seen, but a well drilled at the Canadian Border Station is reported to have penetrated sand and gravel to the total depth of 104 feet. The terrace upon which the border station is situated is deeply incised by Boundary Creek, east of the Kettle River near the international boundary. How ever, west of the Kettle River it is not so deeply incised. The city of Midway, British Columbia (not shown in fig. 3 ), is on a welldefined low terrace about 20 feet above river level. No exposures of the low-terrace de posits in this area were observed. However. logs of wells in Midway typically report 20 to 30 feet of medium to coarse gravel underlain by a bed of light-colored clay averaging about 20 feet in thickness. This clay bed is underlain by an unknown thickness of medium sized gravel.

The channel of the Kettle River is in floodplain deposits of Recent age. The upper few feet of these deposits consists of very coarse gravel and well-rounded cobbles. The width of the flood-plain deposits ranges from about $\frac{1}{4}$ to more than $\frac{1}{2}$ mile.

\section{GROUND-WATER CONDITIONS AT FERRY}

No wells are known to exist on the high outwash terrace, and nothing is known of the 
CANADA

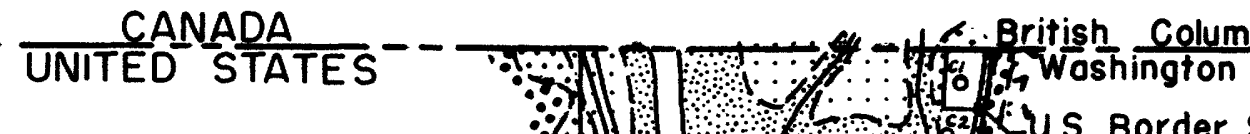

$\because 1$ il : Boundory $1 \%$ Ferry

4
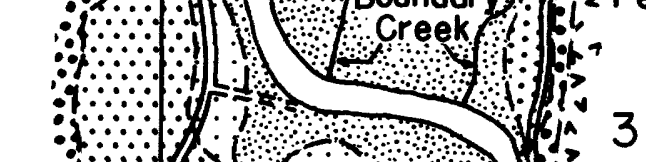

\section{3}

9

Ferry

\section{EXPLANATION}

Flood-plain deposits

$\therefore$ Low-terrace deposits

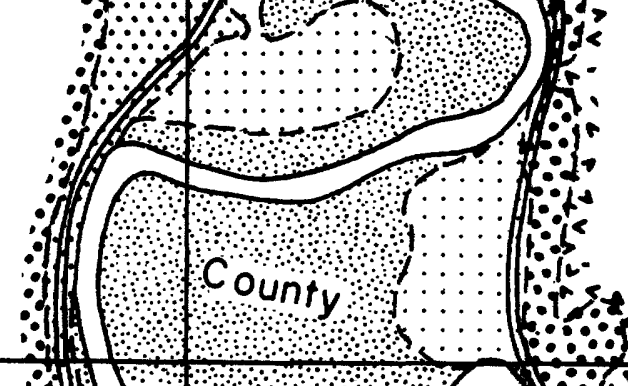

T.

40

N.

$\because \because$ Intermediate-terrace deposits

:::3 High-terrace deposits

[2] Intrusive igneous rocks

$\mathrm{O}_{\mathrm{Cl}}$ Well

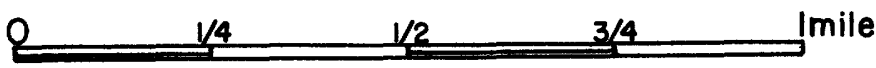

Figure 4. -Geological features and location of selected wells in the Kettle River valley at Ferry, Wash. 
water-bearing characteristics of these deposits; however, it is probable that small yields could be developed from wells, except locally where bedrock lies above the water table beneath the terrace.

The United States Border Station at Ferry obtains its water supply from well 40/32-3C1 (fig. 4), a 6 -inch drilled well reported to be about 97 feet deep. The static water level is reported to be 77 to 82 feet below the land surface. After the well is pumped at the rate of about $10 \mathrm{gpm}$ for 1 to $1 \frac{1}{2}$ hours the water level is lowered to the bottom of the pump suction pipe, which is reported to be near the bottom of the well. The casing of this well reportedly has no perforations or screen, and all the water enters the well through the open bottom of the casing. A well in which only the lower end of the casing is open to water-yielding materials is inefficient. This type of construction may be the cause of the inadequate yield of the well.

For maximum yield, wells constructed on the border-station terrace should penetrate and be perforated opposite the entire thick- ness of sand and gravel, except for a section of blank casing extending far enough below the surface to prevent pollution. When the well or wells are pumped, it is likely that a hydraulic gradient from Boundary Creek or Kettle River toward the well would be established and ground-water recharge to the aquifer thus would be induced.

On the low terrace and the flood plain, small to moderate yields are obtained from shallow driven or dug wells tapping sand and gravel. Well 40/32-3C2 (fig. 4), an unused dug well 8.5 feet deep, has a static water level 4.10 feet below land surface. The yield of this well is not known. On the low terrace large yields are obtained by extending, wells through the light-colored clay bed into the underlying gravel. There are several irrigation wells on the low terrace in the Midway area. No information was obtained on the water-yielding character of the bedrock in the Ferry area, but it appears to be relatively impermeable and probably only very meager quantities of water could be obtained from wells that might be drilled into it. 